\title{
INDICATORS OF VIOLENCE AGAINST WOMEN ACCORDING TO THE REPORTS OF HEALTH SERVICES IN THE STATE OF MINAS GERAIS-BRAZIL
}

\author{
Júlia de Oliveira Andrade ${ }^{1}$, Sybelle de Souza Castro², Sara Franco Diniz Heitor ${ }^{3}$, Wanderson Pereira de Andrade ${ }^{4}$, \\ Camila Cristina Atihe $e^{5}$
}

\begin{abstract}
${ }^{1}$ Undergraduate student, Medical Undergraduate Program Universidade Federal do Triângulo Mineiro (UFTM). Uberaba, Minas Gerais, Brazil. E-mail: juliaandradeuftm@gmail.com

2 Ph.D. in Public Health Nursing. Professor, Departamento de Medicina Social, UFTM. Uberaba, Minas Gerais, Brazil. E-mail: sybelle@ mednet.com.br

${ }^{3}$ Ph.D. student, Programa de Pós-Graduação em Atenção à Saúde, UFTM. Uberaba, Minas Gerais, Brazil. E-mail: sarafdh42@hotmail.com

${ }^{4}$ Medical resident, UFTM. Uberaba, Minas Gerais, Brazil. E-mail: wandaowpa@yahoo.com.br

${ }^{5}$ Medical resident, Universidade Estadual de Campinas. Campinas, São Paulo, Brazil. E-mail: camilaatihe@gmail.com
\end{abstract}

\begin{abstract}
Reports of violence against adult women in Minas Gerais, Brazil were analyzed by consulting the Notifiable Diseases Information System in order to characterize the victims and cases of abuse, calculate morbidity and mortality, and assess the quality of the information. This descriptive retrospective study realized between from 2011-2012. Most women were 20 to 29 years old, Caucasian, married, and were physically abused at home, in which physical strength was used on the head. The number of reports increased $41 \%$ between the two years under study. Mortality stood out among women aged between 30 and 39 years old, lethality was more frequent among 80 year-old or older women, and a greater incidence of physical violence was observed among women between 20 and 29 years old. Reporting forms were incomplete. The proper completion of reporting forms should be encouraged due to the importance of violence reporting in the context of integral care provided to women who are victims of violence.
\end{abstract}

DESCRIPTORS: Violence against women. Health information systems. Public health surveillance.

\section{INDICADORES DA VIOLÊNCIA CONTRA A MULHER PROVENIENTES DAS NOTIFICAÇÕES DOS SERVIÇOS DE SAÚDE DE MINAS GERAIS-BRASIL}

RESUMO: Analisou-se os casos notificados de violências contra a mulher adulta no Estado de Minas Gerais, Brasil, por meio do Sistema de Informação de Agravos de Notificação, com o intuito de caracterizar as vítimas e as situações de abuso, calcular indicadores de morbimortalidade e avaliar a qualidade da informação. Estudo descritivo, retrospectivo, período 2011-2012. A maioria das mulheres era branca, 20 a 29 anos, casada, agredida fisicamente na sua residência, por meio de força corporal, na cabeça. Houve aumento de $41 \%$ nas notificações entre os dois anos analisados. A mortalidade se destacou nas vítimas com 30-39 anos, a letalidade acima de 80 anos, maior incidência para violência física, entre 20-29 anos. Houve incompletude no preenchimento das fichas de investigação. Necessita-se otimizar a completude das fichas de investigação, em razão da importância dessa notificação no contexto da atenção integral às mulheres vítimas de violência.

DESCRITORES: Violência contra a mulher. Sistema de informação em saúde. Vigilância em saúde pública.

\section{INDICADORES DE VIOLENCIA CONTRA LAS MUJERES PROCEDENTES DE LAS NOTIFICACIONES DE LOS SERVICIOS DE SALUD DE MINAS GERAIS- BRASIL}

RESUMEN: Se analizaron los casos notificados de violencia contra la mujer adulta en Minas Gerais, Brazil, a través del Sistema de Información de Agravios de Notificación, con el fin de caracterizar las víctimas y las situaciones abusivas, calcular indicadores de morbilidad y mortalidad y evaluar la calidad de la información. El estudio es descriptivo, retrospectivo y periodo 2011-2012. La mayoría de las mujeres era blanca, 20-29 años, casadas, agredidas físicamente en su residencia, por medio de fuerza corporal en la cabeza. Hubo un aumento del $41 \%$ en las notificaciones entre los años analizados. La mortalidad se destacó en las víctimas con 30-39 años, la letalidad arriba de 80 años, y la mayor incidencia en la violencia física, entre 20-29 años. Muchas fichas de investigación quedaron incompletas. Es necesario optimizar y concientizar sobre completar la ficha de investigación, debido a la importancia de esa notificación en el contexto de atención integral a las mujeres víctimas de violencia.

DESCRIPTORES: Violencia contra la mujer. Sistemas de información en salud. Vigilancia en salud pública. 


\section{INTRODUCTION}

Violence against women involves various aspects, violates human rights and harms the victims' physical and mental health, affecting families and the society as a whole. ${ }^{1}$ This type of violence reflects "any gender-based action or behavior that causes the death or physical, sexual or psychological harm to women both in the public and private spheres". 2:19 It usually occurs in the domestic environment and often involves the use of alcohol and illegal substances on the part of the offender. It tends to follow a progressive pattern, starting with psychological violence, followed by physical violence and sometimes ending in sexual violence. ${ }^{3-4}$

Various factors are described as causing tensions that lead to aggressions, such as economic and social differences between genders, the current financial independence of women, the need for selfassertion on the part of men, and the inclusion of women in the educational system and job market. ${ }^{5-6}$

Chauvinism and patriarchy are also considered frequent causes of violence against women. Chauvinism embeds the idea in the society that men are stronger and more competent than women, both physically and psychologically, while patriarchy establishes a social organization in which men are the center and head of the family, naturalizing gender differences and the female submission in the family dynamics. ${ }^{7}$ Both can harm women's health and also affect children, with behavioral, psychological, interpersonal, economic and professional consequences. ${ }^{3,6,8}$

Despite the enactment of the Maria da Penha Law, which helps to prevent coercion, ${ }^{9}$ and the Politica Nacional de Enfrentamento à Violência Contra a Mulher [National Policy to Cope with Violence Against Women], created by the Brazilian Federal Government to fight violence and provide qualified care to women through Primary Health Care, ${ }^{3}$ women are often afraid and do not seek health services when they face a situation of violence, out of fear of being re-victimized. . $3,8,10$ Additionally, there is a lack of preparation on the part of health workers regarding how to approach a victim and how to systematize care. This is mainly due to a lack of specific protocols addressing technical and scientific parameters to guide care delivery and referrals., ${ }^{3,10}$ There is only a specific national protocol, related to sexual violence, but few health workers are aware of it.
In 2004, a decree established mandatory reporting of violence against women, approving the reporting form to be used and its flow. ${ }^{11}$ It is worth noting that health workers or those responsible for providing care to patients are obliged to report violence. The reporting and data collection forms used in healthcare services and which fed the SINAN (Notifiable Diseases Information System) in the study period was the Ficha de Notificação/ Investigação Individual de Violência Doméstica, Sexual e/ou outras Violências [Reporting Form/Individual Investigation of Domestic, Sexual and/or Types of Violence]. ${ }^{12}$

Given the previous discussion, this study's objective was to analyze reported violence against adult women in the state of Minas Gerais, Brazil, in 2011 and 2012, through SINAN, in order to characterize the victims and abuse, calculate morbidity and mortality rates, and assess the quality of information provided.

\section{METHOD}

This retrospective study with a territorial basis included all reporting forms concerning violence against adult women (age $\geq 19$ years old) ${ }^{*}$ submitted in 2011 and 2012 in the state of Minas Gerais, Brazil. The database was requested in May 2014. The inclusion criteria were: reports should have been submitted in Minas Gerais and victims should reside in the state.

Population data necessary to calculate morbidity and mortality rates were made available by the Brazilian Institute of Geography and Statistics (IBGE) on the DATASUS (SUS Department of Informatics) website. 2011 and 2012 were selected because population estimates by sex and age were available for these years and used in the development of indicators. Aggregated data for both years were used to characterize the cases. Otherwise, the analysis would not present significant differences. The 2012 database was used to calculate the incidence, mortality and lethality rates because it contained a larger number of reports.

Data were analyzed in SPSS version 20.0. The indicators used in the study included accumulated incidence coefficients, mortality and lethality by age and types of violence. The coefficients of incidence and mortality were expressed as number of cases or deaths per 100,000 inhabitants/year.

* Law 8.069 from July $13^{\text {th }}, 1990$. Child and adolescent statute considers that adolescence ends at the age of 18 years. 
The secondary database, SINAN, was provided by the Minas Gerais State Department of Health, based on the standardized reporting form for the entire Brazilian territory..$^{12}$ Even though each report of violence against a woman means a hazard to health that may lead to relapse, each report was considered a new event.

The variables included in the analysis were age, race, education, whether the victim had some disability/disorders, type of violence, means of aggression, nature of injury, part of the body affected, type of sexual violence, type of penetration, area and place where the violence took place, referral to the health sector or others sectors, and how the case progressed.

How well the variables were completed was assessed using criteria proposed by the Economic Commission for Latin America and the Caribbean (CEPAL), according to which, when there is up to $5 \%$ of incomplete information (information that is ignored or unanswered questions), completion is considered to be excellent, from $5 \%$ to $10 \%$ of missing information it is considered good, from $10 \%$ to $20 \%$ regular, poor when between $20 \%$ and $50 \%$ of information is missing, and very poor when more than $50 \%$ of information has been ignored. ${ }^{13-14} \mathrm{We}$ opted for analyzing data that presented $80 \%$ or more of complete information.

The project received approval from the Research Ethics Committe at the Universidade Federal do Triângulo Mineiro (Report 1880/2011). The database did not contain the victims' personal identification. The study complied with National Health Council Resolution 466/12.

\section{RESULTS}

Between 2011 and 2012, 19,213 cases of violence against women were reported in Minas Gerais: 7,995 were reported in 2011, resulting in an incidence of 111.61 cases /100,000 women; and 11,218 were reported in 2012 with an incidence of 155.61 cases/100,000 women, that is, reports increased approximately $41 \%$ from one year to another.

Of the 853 cities in the state of Minas Gerais, $336(39.3 \%)$ reported violence against women in 2011, the cities presenting the highest number of reports being Viçosa (10.5\%) and Belo Horizonte (5.7\%). In 2012, the highest number of cases was reported in Belo Horizonte (8.2\%), followed by Viçosa (3.8\%). Additionally, 591 cities reported cases of violence against women, $56.8 \%$ more than in 2011.
Most abused women were between 20 and 29 years old $(36.9 \%)$, Caucasian $(37.9 \%)$, and married $(40.2 \%)$ (Table 1$)$. The woman's partner was the abuser most frequently reported $(27.9 \%)$, followed by self-infliction $(14.5 \%)$. The women's residences were the place where aggressions took place most frequently $(62.2 \%)$, the head/face was the part of the body most frequently affected $(27.6 \%)$, and most cases progressed to discharge $(87.1 \%)$. Note that 193 deaths caused by violence were reported in the period (Table 2).

Table 1 - Socioeconomic profile of violence against women reported to the Notifiable Diseases Information System, Minas Gerais, Brazil, 20112012. $(\mathrm{N}=19.213)$

\begin{tabular}{|c|c|c|}
\hline Variables & $\mathbf{N}$ & $\%$ \\
\hline \multicolumn{3}{|l|}{ Age } \\
\hline 19 years old & 748 & 3.90 \\
\hline 20 to 29 years old & 7,081 & 36.90 \\
\hline 30 to 39 years old & 5,772 & 30.00 \\
\hline 40 to 49 years old & 3,176 & 16.50 \\
\hline 50 to 59 years old & 1,404 & 7.30 \\
\hline 60 to 69 years old & 589 & 3.10 \\
\hline 70 to 79 years old & 281 & 1.50 \\
\hline 80 years old or older & 162 & 0.80 \\
\hline \multicolumn{3}{|l|}{ Race } \\
\hline Caucasian & 7,279 & 37.90 \\
\hline Afro-descendent & 2,344 & 12.20 \\
\hline Asian & 186 & 1.00 \\
\hline Mixed & 5,753 & 29.90 \\
\hline Indigenous & 126 & 0.70 \\
\hline Blank/Ignored & 3,525 & 18.30 \\
\hline \multicolumn{3}{|l|}{ Education } \\
\hline Illiterate & 321 & 1.70 \\
\hline $1^{\text {st }}$ to incomplete $4^{\text {th }}$ grade & 1,449 & 7.80 \\
\hline Complete $4^{\text {th }}$ grade & 957 & 5.00 \\
\hline $5^{\text {th }}$ to incomplete $8^{\text {th }}$ grade & 2,777 & 14.50 \\
\hline Complete $9^{\text {th }}$ & 1,234 & 6.40 \\
\hline Incomplete high school & 1,156 & 6.00 \\
\hline Complete high school & 2,045 & 10.60 \\
\hline Incomplete College Education & 386 & 2.00 \\
\hline Bachelor's degree & 438 & 2.30 \\
\hline Does not apply & 3 & 0.01 \\
\hline Blank/Ignored & 8,397 & 43.70 \\
\hline \multicolumn{3}{|l|}{ Marital Status } \\
\hline Single & 5,607 & 29.20 \\
\hline Married/fixed partner & 7,716 & 40.20 \\
\hline Separated & 1,459 & 7.60 \\
\hline Widowed & 632 & 3.30 \\
\hline Does not apply & 161 & 0.80 \\
\hline Blank/Ignored & 3,638 & 19.00 \\
\hline
\end{tabular}


Table 2 - Epidemiological profile of violence against women reported to the Notifiable Diseases Information System, Minas Gerais, Brazil, 20112012. $(\mathrm{N}=19,213)$

\begin{tabular}{lrc}
\hline Variables & N & $\%$ \\
\hline Kinship/relationship with abuser & & \\
Father & 165 & 0.90 \\
Mother & 139 & 0.70 \\
Stepfather & 53 & 0.30 \\
Spouse & 5,365 & 27.90 \\
Former spouse & 1,417 & 7.40 \\
Boy/girlfriend & 767 & 4.00 \\
Former boy/girlfriend & 525 & 2.70 \\
Son/daughter & 709 & 3.70 \\
Brother/sister & 495 & 2.60 \\
Friend/acquaintances & 1,678 & 8.70 \\
Unknown person & 1,282 & 6.70 \\
Caregiver & 28 & 0.10 \\
Employer/boss & 21 & 0.10 \\
Institutional relationship & 82 & 0.40 \\
Policeperson/agent of law & 73 & 0.40 \\
The person herself & 2,784 & 14.50 \\
Others & 939 & 4.90 \\
Place of occurrence & & \\
Home & 11,953 & 62.20 \\
Collective housing & 87 & 0.50 \\
School & 76 & 0.40 \\
Place of sports practice & 32 & 0.20 \\
Pub or similar & 443 & 2.30 \\
Public area & 2,555 & 13.10 \\
Business/service area & 219 & 1.10 \\
Construction/industry & 16 & 0.10 \\
Others & 588 & 3.10 \\
Blank/Ignored & 3,244 & 16.90 \\
Recurrence & & \\
Yes & 6,728 & 35.00 \\
No & 6,465 & 33.60 \\
Blank/Ignored & 6,020 & 31.40 \\
& &
\end{tabular}

\begin{tabular}{lrc}
\hline Variables & N & $\%$ \\
\hline Body part affected & & \\
Head/face & 5,311 & 27.60 \\
Neck & 646 & 3.40 \\
Mouth/teeth & 256 & 1.30 \\
Spine/marrow & 117 & 0.60 \\
Thorax/torso & 734 & 3.80 \\
Abdomen & 386 & 2.00 \\
Hip/pelvis & 91 & 0.50 \\
Upper limbs & 2,773 & 14.40 \\
Lower limbs & 805 & 4.20 \\
Genitals/anus & 333 & 1.70 \\
Multiple organs & 2,793 & 14.50 \\
Does not apply & 2,827 & 14.70 \\
Blank/Ignored & 2,141 & 11.10 \\
Offender is suspected of having used & & \\
alcohol & & \\
Yes & 5,907 & 30.70 \\
No & 5,829 & 30.40 \\
Blank/Ignored & 7,477 & 38.90 \\
Case progression & & \\
Discharge & 16,738 & 87.10 \\
Evasion/escape & 234 & 1.20 \\
Death caused by violence & 193 & 1.00 \\
Death due to other causes & 24 & 0.10 \\
Blank/Ignored & 2,024 & 10.60 \\
\hline
\end{tabular}

With regard to the type of violence, physical $(81 \%)$ and psychological $(28.2 \%)$ violence was the most frequently reported, while physical strength/ beating was the most common means of aggression $(62.8 \%)$, followed by threat $(15.6 \%)$ and poisoning $(11.5 \%)$. Sexual violence represented $5.6 \%$ of the cases, while $14.4 \%$ of missing information was observed in the period (Table 3). The most frequently reported type of violence was rape $(4.5 \%)$, followed by sexual harassment with $0.9 \%$. In cases in which penetration was reported, vaginal penetration was the most frequent $(4.0 \%)$.

Table 3 - Distribution of frequency of types and means of violence against women, Minas Gerais, Brazil, 2011-2012. (N=19.213)

\begin{tabular}{lrrrrrr}
\hline Variables & \multicolumn{2}{c}{ Yes } & \multicolumn{2}{c}{ No } & \multicolumn{2}{c}{ Blank/ignored } \\
& $\mathbf{N}^{*}$ & $\%$ & $\mathbf{N}$ & $\%$ & $\mathbf{N}$ & $\%$ \\
\hline Types of violence & & & & & & \\
$\quad$ Financial & 343 & 1.80 & 15,987 & 83.20 & 2,883 & 15.00 \\
$\quad$ Physical & 15,557 & 81.00 & 2,617 & 13.60 & 1,039 & 5.40 \\
$\quad$ Legal intervention & 51 & 0.30 & 16,211 & 84.40 & 2,951 & 15.40 \\
Neglect & 212 & 1.10 & 16,141 & 84.00 & 2,860 & 14.90 \\
Psychological & 5,423 & 28.20 & 11,169 & 58.10 & 2,621 & 13.60 \\
Sexual & 1,071 & 5.60 & 15,362 & 80.00 & 2,780 & 14.40 \\
Torture & 573 & 3.00 & 15,721 & 81.80 & 2,919 & 15.20 \\
$\quad$ Human trafficking & 14 & 0.10 & 16,316 & 84.90 & 2,883 & 15.00 \\
& & & & & & \\
\hline
\end{tabular}




\begin{tabular}{lrccccc}
\hline Variables & \multicolumn{2}{c}{ Yes } & \multicolumn{2}{c}{ No } & \multicolumn{3}{c}{ Blank/ignored } \\
& $\mathbf{N}^{*}$ & $\mathbf{0}$ & $\mathbf{N}$ & $\mathbf{0}$ & $\mathbf{N}$ & $\mathbf{3}$ \\
\hline Other & 1,495 & 7.80 & 14,655 & 76.30 & & 3,063 \\
Means of aggression & & & & & & \\
Threat & 2,995 & 15.60 & 13,112 & 68.20 & 3,106 & 16.10 \\
Firearm & 331 & 1.70 & 15,738 & 81.90 & 3,144 & 16.40 \\
Hanging & 922 & 4.80 & 15,182 & 79.00 & 3,109 & 16.20 \\
Poisoning & 2,201 & 11.50 & 14,207 & 73.90 & 2,805 & 14.60 \\
Physical strength/beating & 12,067 & 62.80 & 5,410 & 28.20 & 1,736 & 9.00 \\
Blunt object & 969 & 5.00 & 15,147 & 78.80 & 3,097 & 15.80 \\
Cutting-piercing object & 1,470 & 7.70 & 14,727 & 76.70 & 3,016 & 15.70 \\
Hot substance/object & 149 & 0.80 & 15,917 & 82.80 & 3,147 & 16.40 \\
Others & 1,420 & 7.40 & 14,213 & 74.00 & 3,580 & 18.60 \\
\hline
\end{tabular}

*Some events included more than one type and means of aggression.

When types of violence were related to age, the group with the highest number of report was that of women aged from 20 to 29 years old, in which physical violence $(30.3 \%)$ predominated, followed by psychological $(9.9 \%)$ and sexual $(2.2 \%)$ violence. The second most affected group included women aged from 30 to 39 years old, in which physical violence $(24.6 \%)$ was also the most common, followed by psychological $(8.7 \%)$, sexual (1.4\%) violence, and torture $(1.0 \%)$. A higher incidence of physical (335.7 cases $/ 100,000$ women) and psychological violence (109.6 cases/100,000 women) was observed among women aged from 20 to 29 years old, while sexual violence was the most common among 19 year-old women (38.6 cases/100,000 women) (Table 4).

Table 4 - Distribution of frequency, proportion and incidence of violence according to type of aggression and age, Minas Gerais, Brazil, 2012. (N=19.213)

\begin{tabular}{|c|c|c|c|c|c|c|c|c|c|}
\hline $\begin{array}{c}\text { Types of } \\
\text { violence* }\end{array}$ & & $\begin{array}{l}19 \text { years } \\
\text { old }\end{array}$ & $\begin{array}{c}20 \text { to } 29 \\
\text { years old }\end{array}$ & $\begin{array}{c}30 \text { to } 39 \\
\text { years old }\end{array}$ & $\begin{array}{c}40 \text { to } 49 \\
\text { years old }\end{array}$ & $\begin{array}{c}50 \text { to } 59 \\
\text { years old }\end{array}$ & $\begin{array}{c}60 \text { to } 69 \\
\text { years old }\end{array}$ & $\begin{array}{c}70 \text { to } 79 \\
\text { years old }\end{array}$ & $\begin{array}{l}80 \text { years } \\
\text { old or } \\
\text { older }\end{array}$ \\
\hline \multirow[t]{3}{*}{ Financial } & $\mathrm{N}$ & 4 & 83 & 104 & 54 & 32 & 31 & 17 & 18 \\
\hline & $\%$ & 0.02 & 0.40 & 0.50 & 0.30 & 0.20 & 0.20 & 0.09 & 0.09 \\
\hline & I & 2.30 & 4.80 & 6.70 & 3.79 & 2.78 & 4.40 & 3.90 & 8.10 \\
\hline \multirow[t]{3}{*}{ Physical } & $\mathrm{N}$ & 612 & 5,831 & 4,722 & 2,550 & 1,118 & 455 & 183 & 86 \\
\hline & $\%$ & 3.20 & 30.30 & 24.60 & 13.30 & 5.80 & 2.40 & 1.00 & 0.40 \\
\hline & I & 325.70 & 335.70 & 304.70 & 178.80 & 97.10 & 64.60 & 42.40 & 38.60 \\
\hline \multirow{3}{*}{$\begin{array}{l}\text { Legal interven- } \\
\text { tion }\end{array}$} & $\mathrm{N}$ & 2 & 15 & 17 & 9 & 5 & 3 & 0 & 0 \\
\hline & $\%$ & 0.01 & 0.08 & 0.09 & 0.05 & 0.03 & 0.02 & 0.00 & 0.00 \\
\hline & I & 1.20 & 0.90 & 1.10 & 0.60 & 0.40 & 0.4 & 0 & 0 \\
\hline \multirow[t]{3}{*}{ Neglect } & $\mathrm{N}$ & 6 & 25 & 24 & 20 & 15 & 19 & 50 & 53 \\
\hline & $\%$ & 0.03 & 0.10 & 0.10 & 0.10 & 0.08 & 0.10 & 0.30 & 0.30 \\
\hline & I & 3.40 & 1.40 & 1.50 & 1.40 & 1.30 & 2.70 & 11.60 & 23.80 \\
\hline \multirow[t]{3}{*}{ Psychological } & $\mathrm{N}$ & 187 & 1,903 & 1,671 & 908 & 397 & 209 & 85 & 63 \\
\hline & $\%$ & 0.90 & 9.90 & 8.70 & 4.70 & 2.00 & 1.10 & 0.40 & 0.30 \\
\hline & I & 107.70 & 109.60 & 107.80 & 63.70 & 34.50 & 29.60 & 19.70 & 28.30 \\
\hline \multirow[t]{3}{*}{ Sexual } & $\mathrm{N}$ & 67 & 427 & 275 & 183 & 68 & 26 & 13 & 12 \\
\hline & $\%$ & 0.40 & 2.20 & 1.40 & 1.00 & 0.30 & 0.10 & 0.07 & 0.06 \\
\hline & I & 38.60 & 24.60 & 17.70 & 12.80 & 5.90 & 3.70 & 3.00 & 5.40 \\
\hline \multirow[t]{3}{*}{ Torture } & $\mathrm{N}$ & 17 & 185 & 195 & 99 & 43 & 19 & 10 & 5 \\
\hline & $\%$ & 0.10 & 1.00 & 1.00 & 0.50 & 0.20 & 0.10 & 0.05 & 0.03 \\
\hline & I & 0.60 & 0.10 & 0.10 & 0.00 & 0.20 & 0.00 & 0.00 & 0.00 \\
\hline \multirow[t]{3}{*}{ Other } & $\mathrm{N}$ & 50 & 512 & 471 & 293 & 120 & 34 & 10 & 5 \\
\hline & $\%$ & 0.30 & 2.60 & 2.40 & 1.50 & 0.60 & 0.20 & 0.05 & 0.03 \\
\hline & I & 28.80 & 29.50 & 30.40 & 20.50 & 10.40 & 4.80 & 2.30 & 2.20 \\
\hline
\end{tabular}

I = accumulated incidence in 2012 (per 100,000 women); *Some reports included more than one type of violence in the same event. 
Mortality was the most frequent among women aged from 30 to 39 years old (18 deaths/100,000 women) and between 20 and 29 years old (16 deaths $/ 100,000$ women). In terms of types of violence, mortality was higher in cases in which physical violence was involved (1 death/100,000 women). Lethality was more severe among women aged 80 years old or older $(3.5 \%)$, followed by those aged between 60 and 69 years old $(2.1 \%)$, and in cases in which violence was related to human trafficking $(10 \%)$ and neglect (3\%) (Table 5).

Table 5 - Distribution of mortality and lethality rates caused by violence against women according to age and type of violence, Minas Gerais, Brazil, 2012. $(\mathrm{N}=19.213)$

\begin{tabular}{lcc}
\hline Variables & $\begin{array}{c}\text { Mortality } \\
(\mathbf{1 0 0 , 0 0 0} \text { women) }\end{array}$ & Lethality (\%) \\
\hline Age & & \\
19 years old & 1.00 & 0.30 \\
20 to 29 years old & 16.00 & 0.70 \\
30 to 39 years old & 18.00 & 1.00 \\
40 to 49 years old & 15.00 & 1.40 \\
50 to 59 years old & 9.00 & 1.70 \\
60 to 69 years old & 5.00 & 2.10 \\
70 to 79 years old & 2.00 & 1.60 \\
80 years old or older & 2.00 & 3.50 \\
Types of violence & & \\
Financial & 0.04 & 2.00 \\
Physical & 1.00 & 1.00 \\
Legal intervention & 0.01 & 3.00 \\
Neglect & 0.06 & 3.30 \\
Psychological & 0.20 & 0.60 \\
Sexual & 0.07 & 0.80 \\
Torture & 0.10 & 2.60 \\
Drug trafficking & 0.01 & 10.00 \\
Other & 0.03 & 2.00 \\
\hline
\end{tabular}

Even though $22.2 \%$ of information on how the cases progressed and respective referrals was missing (data not presented in the table), more than half $(52.3 \%)$ was referred to outpatient clinics and most victims were discharged $(87.1 \%) ; 1.0 \%$ of these women, however, died due to the consequences of the violence.

This analysis presents some limitations, since some variables presented high levels of missing information (more than 20\% of information was ignored or left blank $)^{9}$ and for this reason was not described, such as data concerning violence against pregnant women (28.0\%), level of education (43.7\%), and violence against women with disabilities/disorders $(26.9 \%)$.

\section{DISCUSSION}

Increased reporting on violence against women and increased number of cities reporting such cases observed between the two years under study (2011 and 2012) is relevant and may be explained by greater investment in the qualification of healthcare workers, which improved violence reports ${ }^{15}$ and made the system more sensitive to the identification of cases.

Most professionals in 291 healthcare services in the State of São Paulo, Brazil reported that they complete the mandatory reporting form, though they also reported difficulties regarding work overload and a lack of understanding, in the context of integral care, regarding the importance of such reporting. Strategies intended to encourage workers to adopt violence reporting as part of their practice are necessary, as well as the proper valuation of the care provided to these women as one of the various roles played by healthcare services. ${ }^{16}$ We can empirically observe that nursing professionals file reporting forms in most healthcare services and also adopt the measures required.

Among this study's victims, most were between the age of 20 and 29 years old, which is in agreement with other studies. ${ }^{17-19}$ These findings may reflect the Brazilian culture, in which men, feeling insecure in the face of a woman's beauty at this age and by the fact she may draw attention of other men, act violently and authoritatively. ${ }^{17}$

With regard to the victims' ethnicity, most were Caucasian, followed by mixed race, a result that is in agreement with the population; most people in the state report being Caucasian. Additionally, until recently, violence against Afro-descendent women used to be ignored and underreported. ${ }^{18-20}$

Despite the impossibility of assessing the women's social status and education, due to missing information in the database, a low social status and low level of education may be a point in common among female victims of violence, ${ }^{21}$ though not among all cases; violence does take place in any economic or cultural environment. ${ }^{19,21}$

In terms of marital status, an intimate relationship was observed between victims and offenders as most victims were married, in line with studies in which intimate partners were the offenders, ${ }^{8,19,22}$ due to relationships of dominance and subordination, which coexist with unequal rights, duties and privileges, generating an asymmetric relationship. Despite the suffering caused by domestic violence, many women opted for 
being resilient for the sake of their children, who aroused a feeling of duty and responsibility for their mother role, detaching themselves from the traumatic experience. ${ }^{23}$

The domestic environment was a fertile ground for violence because it is a private place with little interference of other people. ${ }^{17,19,22}$ The Maria $d a$ Penha Law needs to be disseminated, implemented and enforced, ${ }^{8,24}$ with the collaboration of the system of defense, protection and assistance to female victims of violence, together with healthcare services, social welfare, police, legal system, women's police stations and others.

The types of violence most frequently reported were physical and psychological violence, as reported by other studies. ${ }^{17,19}$ There are, however, studies in which this order is inverse, ${ }^{22,15}$ while sexual violence also appears as the most frequent after psychological violence.

Physical strength/beating was the most frequent means of aggression: most women suffered contusions and the most affected part of the body was head/face, which is also in agreement with the reports of other authors. ${ }^{17,19}$ The head/face is a symbolic region that denotes humiliation and represents an act against human dignity. ${ }^{17}$

Psychological violence is still underreported because many women do not seek help, while violence does not become physical. ${ }^{25}$ Psychological violence may be attributed to the devaluation of women, decreasing their self-esteem and, in more severe cases, leading to suicidal thoughts. ${ }^{26}$ Types of violence may overlap in many cases, especially psychological and physical violence. ${ }^{19,25}$

Self-inflicted violence may indicate social discomfort and suffering, as some people see themselves as unable to solve conflicts and opt for taking drastic measures against their own health or life, for instance, intentional intoxication by medication or nonspecific biological substances. ${ }^{27-28}$

Even though one of this study's limitations is the secondary database used, the reporting form contains a variable that distinguishes between new cases and reoccurrences; the latter refers to $35 \%$ of the cases. Thus, one has to take into account that violence can occur in different situations and be characterized by different types of aggression, such as sexual or physical violence, torture, or self-inflicted (suicide and suicide attempts, among others).

Sexual violence tends to go underreported because it makes women feel dirty and ashamed and feel a desire to become invisible. Sexual abuse may lead to anxiety and depression and lead women to abuse of alcohol, drugs or the experience of eating disorders that may last one's entire life. ${ }^{29}$

A small proportion $(0.04 \%)$ of violence related to child labor was found, but it was probably due to some mistake in the completion of forms or typo, since this database includes only 19 year-old or older women.

The consumption of alcohol on the part of offenders was high, despite some missing information. Suspicion of alcohol abuse follows trends reported by other studies, in which the use of alcohol may trigger violent behavior, ${ }^{21,29}$ as well as the use of drugs, which can increase the likelihood of aggression. ${ }^{21}$

The recurrence of violence in this study was two thirds lower than that found in another study. ${ }^{22}$ This difference is partly related to the fact that this variable missed information in the mandatory reporting forms from the State of Minas Gerais. The insistency of women in keeping an affective relationship, hoping the partner will have a change of behavior, as well as financial and emotional dependency established with partners/spouses, may favor the repetition of aggressions. ${ }^{26}$

The repetition of this phenomenon may be an indirect indicator of how weak public policies are in terms of measures aimed to stop violence against women in the State of Minas Gerais, as well as the system that ensures the rights of people, showing that the public sector needs to implement strategies to prevent new cases and recurrences.

Slightly more than half of the reported cases were referred to outpatient clinics, as opposed to a study addressing violence reported in the premises of the Hospital das Clinicas, Universidade Federal de Uberlândia, MG, Brazil, in which only $17.6 \%$ of cases had a similar outcome. This divergence may be explained by the setting where the study was conducted; ${ }^{17}$ this study refers to reports submitted by all health services in the State of Minas Gerais.

A study ${ }^{30}$ that investigated femicides in Brazil considering all ages ${ }^{30}$ verified, similarly to this study, that greater mortality was observed among women aged between 30 and 39 years old and between 20 and 29 years old. Note that female homicides in Brazil represent $10 \%$ of total mortality caused by aggression.

A condition possibly related to mortality rates is the cultural change that has taken place in Brazil, with a massive increase of women entering the job market, enabling them to acquire financial independence, generating conflicts in view of a historically 
chauvinist and patriarchal conception that rules the society, leading to violence and potentially deaths. ${ }^{30}$ Higher levels of urban violence and an increased number of events related to external causes contribute to increased mortality among women.

Over the years, violence started manifesting mainly in the form of abandonment, neglect, physical abuse and economic exploitation, probably due to increased longevity of elderly women. ${ }^{31}$ This study also reveals that lethality was predominant among 80 year-old or older women, which may also be related to associated comorbidities present at this age. ${ }^{31}$ Violence against the elderly more frequently occurs at home, ${ }^{32-33}$ which may be caused by a sense of devaluation of seniors and when different generations live together. When various family members live in the same home, conflict of generation and values may arise and be worsened by the senior's vulnerability or frailty, ${ }^{34}$ and also exacerbated by relationships in which financial dependence, weak affective bonds, or the presence of any mental or psychiatric disorder exist, among others. ${ }^{35}$

\section{CONCLUSION}

Violence against adult women most frequently affected young women, between 20 and 39 years of age, Caucasian or mixed race individuals, married or with a fixed partner, while their spouses were most frequently the offenders. Violence in general took place in the victim's household and in most cases the care provided at the health services progressed to discharge. Women were mainly victims of physical violence, that is, physical strength/beating, and were hit on their heads/faces; the second most frequent type of violence was threat. Mortality was higher among women aged between 30 and 39 years old, mainly caused by physical violence; lethality was higher among 80 year-old or older women.

Information missing in some of the fields of reporting forms shows the need to qualify professionals and incorporate epidemiological surveillance actions to the work routine of healthcare services, as well as to disseminate the flow of victims cared for in the healthcare system to improve the completion of reporting forms and grant visibility to the importance of implementing measures that ensure the rights of women experiencing violence.

\section{REFERENCES}

1. World Health Organization (WHO), London School of Hygiene and Tropical Medicine. Preventing intimate partner and sexual violence against women: taking action and generating evidence. Geneva: WHO; 2010.

2. Secretaria de Políticas para as Mulheres (BR). Política Nacional de enfrentamento à violência contra as mulheres. Brasília: Presidência da República; 2011.

3. Osis MJD, Duarte GA, Faúndes A. Violência entre usuárias de unidades de saúde: prevalência, perspectiva e conduta de gestores e profissionais. Rev Saúde Pública. 2012 Abr; 46(2):351-8.

4. Sánchez PM, Parra SG, Garcia OM. Violencia basada en género en zonas urbanas y urbano-marginales de Lima y Callao, 2007-2010. An Fac Med. 2012 Mai; 73(2):127-33.

5. Moura LBA, Gondolfi L, Vasconcelos AMN, Pratesi R. Violências contra mulheres por parceiro íntimo em área urbana economicamente vulnerável. Rev Saúde Pública. 2009 Dez; 43(6):1-9.

6. Miranda MPM, Paula CS, Bordin IA. Violência conjugal física contra a mulher na vida: prevalência e impacto imediato na saúde, trabalho e família. Rev Panam Salud Publica. 2010 Dez; 27(4):300-8.

7. Santos ACW, Moré CLOO. Repercussão da violência na mulher e suas formas de enfrentamento. Padéia. 2011 Ago; 21(49):227-35.

8. Acosta DF, Gomes VLO, Fonseca AD, Gomes GC. Violence against women commited by intimate partners:(in)visibility of the problem. Texto Contexto Enferm [Internet]. 2015 Jan-Mar [cited 2015 Jul 03]; 24(1):121-7.Available from: http:/ / www.scielo.br/ pdf/tce/v24n1/pt_0104-0707-tce-24-01-00121.pdf

9. Brasil. Lei n. 11.340, de 07 de agosto de 2006. Lei Maria da Penha. Regulamenta ações de enfrentamento à violência contra a mulher. Diário Oficial da União, 07 Ago 2006.

10. Kiss LB, Schraiber LB. Temas médico-sociais e a intervenção em saúde: a violência contra mulheres no discurso dos profissionais. Ciênc Saúde Coletiva. 2011 Abr; 16(3):1943-52.

11. Brasil. Portaria n. 2.406, de 5 novembro de 2004. Institui serviço de notificação compulsória de violência contra a mulher nos serviços de saúde, e aprova instrumento e fluxo para notificação. Diário Oficial da União, 9 Nov. 2004.

12. Ministério da Saúde (BR). Secretaria de Vigilância em Saúde. Instrutivo para preenchimento da Ficha de Notificação/Investigação Individual de Violência Doméstica, Sexual e/ou outras violências no Sistema de Informação de Agravos de Notificação. Brasília (DF): MS; 2011.

13. Romero DE, Cunha CB. Avaliação da qualidade das variáveis sócio-econômicas e demográficas dos óbitos de crianças menores de um ano registrados no Sistema de Informações sobre Mortalidade do Brasil (1996/2001). Cad Saúde Pública. 2006 Mar; 22(3):673-84.

14. Oliveira MEP, Soares MRAL, Costa MCN, Mota ELA. Avaliação da completitude dos registros de febre tifoide notificados no Sinan pela Bahia. Epidemiol 
Serv Saúde. 2009 Set; 18(3):219-26.

15. Veloso MMX, Magalhães CMC, Dell'Aglio DD, Cabral IR, Gomes MM. Notificação da violência como estratégia de vigilância em saúde: perfil de uma metrópole do Brasil. Ciênc Saúde Coletiva. 2013; 18(5):1263-72.

16. Sousa MH, Bento SF, Osis MJD, Ribeiro MP, Faúndes. Filling out the compulsory notification in health services that care for women who suffer from sexual violence. Rev Bras Epidemiol. 2015 Jan-Mar; 18(1):94107.

17. Garcia MV, Ribeiro LA, Jorge MT, Pereira GR, Resende AP. Caracterização dos casos de violência contra a mulher atendidos em três serviços na cidade de Uberlândia, Minas Gerais, Brasil. Cad Saúde Pública. 2008 Nov; 24(11):2551-63.

18. Sousa AKA, Nogueira DA, Gradim CVC. Perfil da violência doméstica e familiar contra a mulher em um município de Minas Gerais, Brasil. Cad Saúde Pública. 2013 Dez; 21(4):425-31.

19. Ministério da Saúde (BR). Secretaria de Vigilância em Saúde. Departamento de Análise de Situação de Saúde. Saúde Brasil 2011: uma análise da situação de saúde e vigilância da saúde da mulher. Brasília (DF): MS; 2012.

20. Silva SG. Preconceito e Discriminação: As Bases da Violência Contra a Mulher. Psicol Cienc Prof. 2010 Set; 30(3):556-71.

21. Deeke LP, Boing AF, Oliveira WF, Coelho EBS. A dinâmica da violência doméstica: uma análise a partir dos discursos da mulher agredida e de seu parceiro. Saúde Soc. 2009 Jun; 18(2):248-58.

22. Vieira LJES, Ferreira RC, Moreira GAR, Gondim APS, Araújo MAL, Silva RM. Fatores associados à sobreposição de tipos de violência contra a mulher notificada em serviços sentinela. Rev Latino-Am Enfermagem. 2013 Ago; 21(4):8 telas .

23. Labronici LM. Resilience in women victims of domestic violence: a phenomenological view. Texto Contexto Enferm [Internet]. 2012 Set [cited 2015 Jul 03]; 21(3):625-32. Available from: http:/ / www.scielo. br/pdf/tce/v21n3/en_v21n3a18.pdf

24. Secretaria de Enfrentamento à Violência Contra
Mulheres (SEV); Pacto Nacional pelo Enfrentamento à violência contra mulher, 2014 [Internet]. 2011 Fev www.spm.gov.br/subsecretaria-de-enfrentamentoa-violencia-contra-mulher

25. Schraiber LB, Latorre MRD, França IJr, Sergri NJ, D'Oliveira AFPL. Validade do instrumento WHO VAW STUDY para estimar violência de gênero contra a mulher. Rev Saúde Pública. 2010 Ago; 44(4):658-66.

26. Zancan N, Wassermann NN V, Lima GQde. A violência doméstica a partir do discurso de mulheres agredidas. Pensando Fam. 2013 Set; 17(1):63-7.

27. Monteiro RA, Bahia CA, Paiva EA, de Sá NNB, Minayo MCS. Hospitalizações relacionadas a lesões autoprovocadas intencionalmente - Brasil, 2002 a 2013. Ciênc Saúde Coletiva. 2015 Jun; 20(3):689-99.

28. Braga LL, Dell'Aglio DD. Suicídio na Adolescência: fatores de risco, depressão e gênero. Contextos Clínicos. 2013 Jan-Jun; 6(1):1-14.

29. Souza FBC, Drezett J, Meirelles AC, Ramos DG. Aspectos psicológicos de mulheres que sofrem violência sexual. Reprod Clim. 2013 Mar; 7(3):98-103.

30. Meneghel SN, Hirakata VN. Femicídios: homicídios femininos no Brasil. Rev Saúde Pública. 2011 Nov; 45(3):564-74.

31. Santos AJ, Nicolau R, Fernandes AA, Gil AP. Prevalência da violência contra as pessoas idosas: uma revisão crítica da literatura. Sociologia, Problemas e Práticas. 2013 Abr; 72 :53-77.

32. Abath MB, Leal MCC, Melo Filho DA. Fatores associados à violência doméstica contra a pessoa idosa. Rev Bras Geriatr Gerontol. 2012; 15(2):305-14.

33. Valadares FC, Souza ER. Violência contra a pessoa idosa: análise de aspectos da atenção de saúde mental em cinco capitais brasileiras. Cien Saude Colet 2010 Set; 15(6):2763-74.

34. Rabelo DF, Neri AL. Tipos de configuração familiar e condições de saúde física e psicológica em idosos. Cad Saúde Pública. 2015 Abr; 31(44):874-84.

35. Minayo MCS, Souza ER. As múltiplas mensagens da violência contra idosos. In: Minayo MCS, Souza ER, organizadores. Violência sob o olhar da saúde: a infrapolítica da contemporaneidade brasileira. Rio de Janeiro (RJ): Editora Fiocruz; 2003. 